\title{
Molecular Processes in Electric Destruction of Nanocomposites Polyethylene + Nanoclay After Exposure to Electric Discharge and Orientation
}

\author{
A. R. Sadygova ${ }^{1}$ I. I. Abbasov' ${ }^{2}$ E. S. Safiev $^{2}$, A. A. Hadiyeva ${ }^{1}$, \\ Kh. O. Sadig ${ }^{2}$, and V. A. Alekperov ${ }^{1}$ \\ ${ }^{1}$ Institute of Physics, N.A.S. of Azerbaijan, \\ 33, H. Javid Ave., \\ AZ-1143 Baku, Azerbaijan \\ ${ }^{2}$ Azerbaijan State Oil and Industry University, \\ 20, Azadlig Ave., \\ AZ-1010 Baku, Azerbaijan
}

It is studied the effect of electric discharge and orientation on the electric lifetime $(\tau)$ and dielectric strength $(E)$ of the polyethylene $(\mathrm{PE})+$ nanoclay (NC) nanocomposites. Changes in the structure of materials under the influence of external factors are determined by infrared spectrometry and compared with their electrical properties. After electric ageing, the rate of formation of carbonyl groups $(\mathrm{C}=\mathrm{O})$ in nanocomposites is comparatively lower than in PE. In destructive processes, NC is much more active than in stabilizing processes.

Досліджено вплив електричного розряду й орієнтації на електричний час життя $(\tau)$ й діелектричну міцність $(E)$ нанокомпозитів поліетилен (ПЕ) + наноглина (НГ). Зміни у структурі матеріялів під впливом зовнішніх чинників визначено методою інфрачервоної спектрометрії і порівняно $з$ їхніми електричними властивостями. Після електричного старіння швидкість утворення карбонільних груп $(\mathrm{C}=\mathrm{O})$ у нанокомпозитах є порівняно більшою, ніж у ПЕ. У деструктивних процесах НГ є набагато активнішою, ніж у стабілізаційних процесах.

Key words: nanocomposite, dielectric strength, lifetime, orientation, carbonyl group.

Ключові слова: нанокомпозит, електрична міцність діелектрика, час життя, орієнтація, карбонільна група.

(Received 18 February, 2020; in revised form, 8 March, 2020) 


\section{INTRODUCTION}

One of the most widely used macromolecular compounds in industry and in everyday life is PE. As an insulating material used in the cable industry and a material for the manufacture of plastic pipes, $\mathrm{PE}$ during operation is exposed to various external factors (mechanical load, electric field and discharges, temperature, radiation, etc.) and is destroyed. To weaken this process or increase the lifetime, a polymer composition is made by introducing additives with different percentages into a pure polymer. By choosing an additive and taking into account its percentage, high-quality products can be obtained from a composite material with suitable properties.

High-quality products from such composite materials during operation are exposed to the above-mentioned external factors and become unusable. Non-recyclable polymer products can lead to environmental pollution. Composite products with improved properties obtained by various methods age over time. Accordingly, the study of the destruction of polymeric materials under the influence of external factors is very important from a scientific and practical point of view. By investigating the cause of the destruction of polymeric substances, it is possible to acquire knowledge in changing their properties, decreasing the rate of destruction (ageing) or increasing the lifetime.

In the cited works [1-5], the mechanical, electrical, optical and other properties of composites were studied: $\mathrm{PE}+$ polypropylene (PP) fibre, $\mathrm{PE}+$ glass fibre, $\mathrm{PE}+$ diamond, $\mathrm{PP}+\mathrm{NC}, \mathrm{PE}+\mathrm{NC}$, etc. with organic and inorganic additives. Analyzing these properties, significant findings have been received on revealing the fracture mechanism of these composites. By studying changes in the structure and mechanical properties of nanocomposites under the influence of external factors, it is possible to approximate their mechanical durability in advance.

\section{PRODUCING OF THE SAMPLES AND MEASUREMENT METHODS}

After mechanically mixing different percentages of NC (1.0-10.0\%) with $\mathrm{PE}$ by hot pressing (425 K, $150 \mathrm{MPa}, 10 \mathrm{~min})$, we get samples with 40-70 microns' thick. In Giannelis's experiments [6], nanocomposites were prepared in three stages (Fig. 1).

At the $1^{\text {st }}$ stage $(a)$, a tactoid is formed; polymer links cover clay agglomerates from the outside. At the $2^{\text {nd }}$ stage $(b)$, the segments of the links entering the voids between the layers contribute to the separation of the layers by $2-3 \mathrm{~nm}$ [7]. At the $3^{\text {rd }}$ stage $(c)$, the clay layers are displaced relative to each other, the layers are disordered 

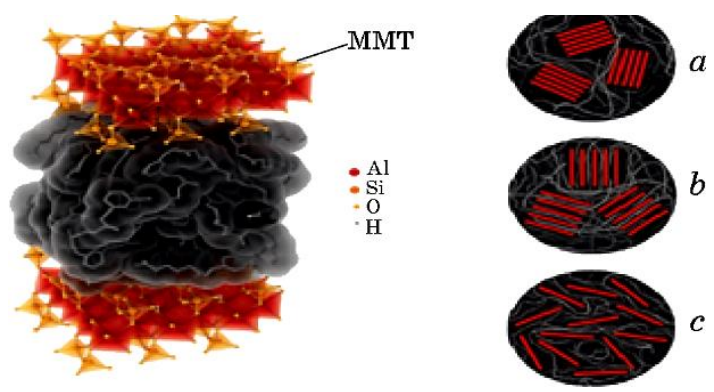

Fig. 1. Three structures of 'polymer-layered silicate' composites.

(disorientation) and complete delaminated. A uniform distribution of clay within the polymer indicates a defect-free nanocomposite structure. To elucidate the role of $\mathrm{NC}$ additives in changing the properties of materials preaged and exposed to electrical discharges at different time periods ( $t=1,2,3,4,5,10,15$ hours) and oriented samples, the lifetime (time-to-puncture) was measured using breakdown installation [8]. To study important structural changes in nanocomposites after exposure to electrical discharges and orientation, the optical density $(D)$ was calculated using IR spectrometry in the frequency range of $500-2700 \mathrm{~cm}^{-1}$ at the corresponding frequency of $1720 \mathrm{~cm}^{-1}$ for the carbonyl group $(\mathrm{C}=0)$, and its value was compared with the dielectric strength.

\section{RESULTS AND DISCUSSION}

The effect of NC on the dielectric strength of PE was previously studied by us [5]. It was shown that the lifetime and dielectric strength change depending on the amount of NC. Investigating the impact of external factors on the lifetime and dielectric strength of PE-based nanocomposites and $\mathrm{NC}$ additives, it is possible to get some information about the mechanism of electrical breakdown (destruction) and the role of NC in this process. It is expedient, therefore, to use two differently influencing factors: 1) destabilizing (electric discharges, electric field, mechanical load, temperature, radiation, emission, etc.), leading to ageing and destruction; 2) stabilizing (orientation, micro- and nanoadditives, fillers, etc.). It is known that electrical ageing of polymers can be carried out by various methods [9, 10]. Ageing of pure polymers and nanocomposites (based on them) during operation occurs for years; therefore, accelerated ageing of materials is carried out under laboratory conditions in special installations. In our research, electric discharge was chosen as a destabilizing factor, and orientation was chosen as a 
stabilizing factor.

Research objects were samples: pure $\mathrm{PE}$ and $\mathrm{PE}+3 \%$ NC. To study the effect of electric discharges the samples in the above time intervals were subjected to ageing at a voltage of $U=9 \cdot 10^{3} \mathrm{~V}$. Figure 2 presents logarithmic dependence of lifetime for samples on electric field strength.

Using this graph, it is possible to construct the dependence of the dielectric strength at $\tau=1 \mathrm{sec}$ on the time of discharge exposure (Fig. 3).

At short time of discharge exposure (1-3 hours), dielectric strength of both samples increases and a decrease in $E$ is observed

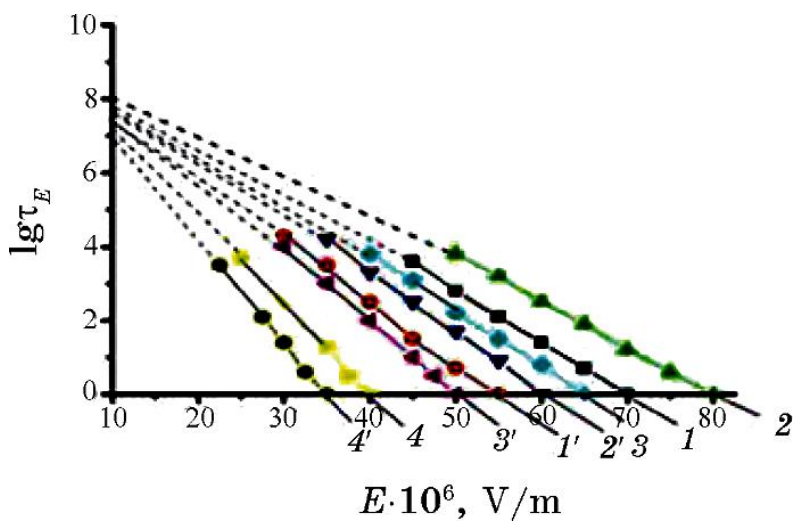

Fig. 2. Dependence $\log \tau_{E}=f(E)$ of $\mathrm{PE}$ and $\mathrm{PE}+3.0 \% \mathrm{NC}$ samples at various ageing times. $1,2,3,4-\mathrm{PE} ; 1^{\prime}, 2^{\prime}, 3^{\prime}, 4^{\prime}-\mathrm{PE}+3.0 \% \mathrm{NC}\left(1.1^{\prime}-t=0\right.$; $2.2^{\prime}-t=3$ hours; $3,3^{\prime}-t=5$ hours; $4,4^{\prime}-t=15$ hours; $\left.T=293 \mathrm{~K}\right)$.

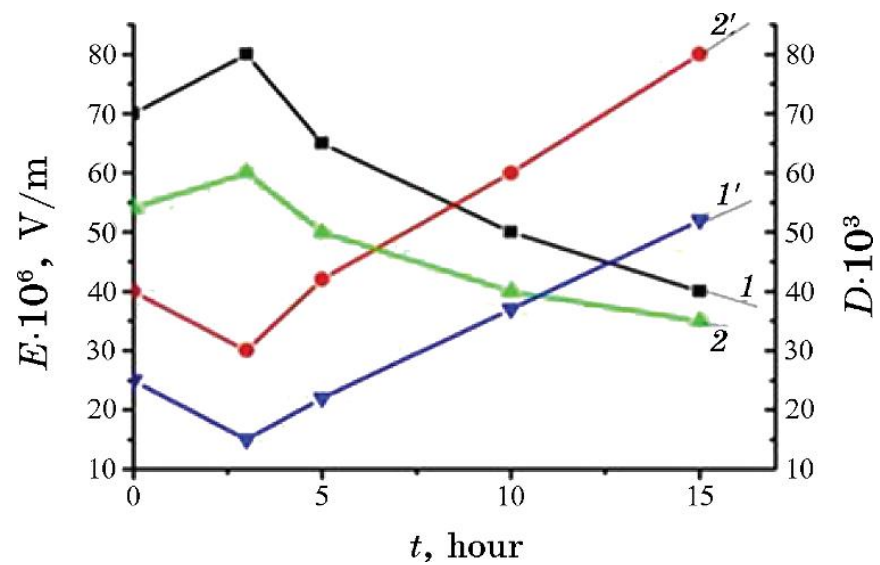

Fig. 3. Dependence of dielectric strength on time of discharge exposure. 1, $1^{\prime}-$ pure $\mathrm{PE} ; 2,2^{\prime}-\mathrm{PE}+3.0 \% \mathrm{NC} ; 1,2-E ; 1^{\prime}, 2^{\prime}-D$. 
with increasing ageing time. For the nanocomposite, the rate of decrease in $E$ is lower than in PE. It is well known that, under the influence of electric discharges, macromolecules oxidize, wear out, amorphous regions soften (bonds are broken, microvoids and cracks are formed, etc.), intermolecular interactions weaken [4, 11]. NC prevents the breaking of bonds, formation of microvoids and cracks under the influence of electric discharges, and thus, prevents the appearance of carbonyl groups in the oxidation process.

The experimental results of the influence of orientation as a stabilizing factor are presented in Fig. 4. With an increase in the degree of orientation, the rate of increase in $E$ of nanocomposite compared to pure PE is insignificant.

To explain the experimental results, changes in the structure of the samples under the influence of electric discharges and orientation were studied by IR spectroscopy. Spectrograms of both samples were recorded in the frequency range of $500-2700 \mathrm{~cm}^{-1}$ (Figs. 5 and $6)$.

At a frequency of $1720 \mathrm{~cm}^{-1}$ corresponding to the carbonyl group $\mathrm{C}=\mathrm{O}$, the intensity of the oxidation peak varies depending on the time of discharge exposure. Calculated from the spectrum, the optical density $D_{1720}$ of the $\mathrm{C}=\mathrm{O}$ group is shown in Fig. 3 . At the initial time of exposure to electric discharges (1-3 hours), $D_{1720}$ decreases; with a further increase in the exposure time, $D_{1720}$ increases. The rate of increase in the optical density of nanocomposite in comparison with PE is low. Depending on ageing, under the influence of a certain tension, initially increasing of $E$ and, then, its decreasing is explained as follows.

In polymers under the action of electric discharges along with oxidative-destructive processes, their macromolecules are crosslinked (net or spatial polymers constructed from long chains connected to each other in a three-dimensional grid with transverse chemical bonds). Short cross-linking time (cross-linking of polymer chains through chemical bonds) is superior to oxidative-destructive processes; therefore, there is no reduction in the dielectric strength for both samples. Accordingly, the optical thickness of the $\mathrm{C}=\mathrm{O}$ groups decreases. With prolonged exposure to electric discharges, with the decay of chemical bonds, the number of $\mathrm{C}=\mathrm{O}$ groups increases. For $t=15$ hours, the value of $E$ decreases in comparison with this parameter at $t=0$, and for both samples, this decrease corresponds to an increase in $D_{1720}$. This shows that there is a correlation between dielectric strength and optical density (Fig. 3, Table).

Comparing the dielectric strength and optical strength of the samples after exposure to electric discharges, it can be noted that NC slowing down the oxidation process plays the role of an antioxi- 


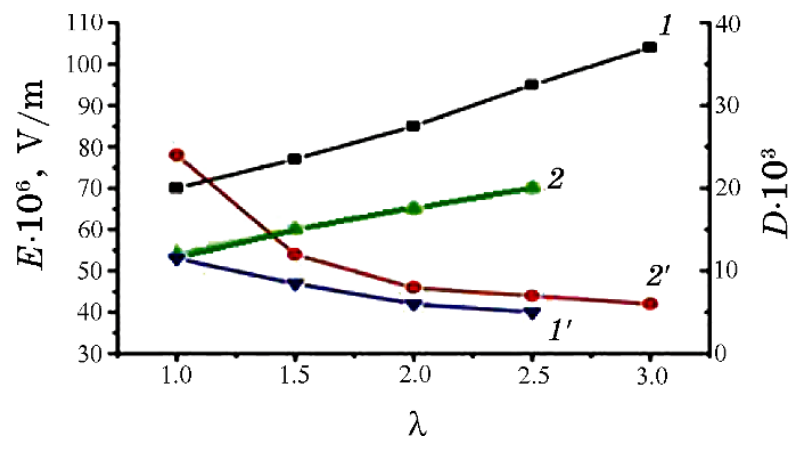

Fig. 4. The dependence of dielectric strength on the degree of orientation: $1,1^{\prime}$-pure PE; $2,2^{\prime}-\mathrm{PE}+3.0 \% \mathrm{NC} ; 1,2-E ; 1^{\prime}, 2^{\prime}-D$.

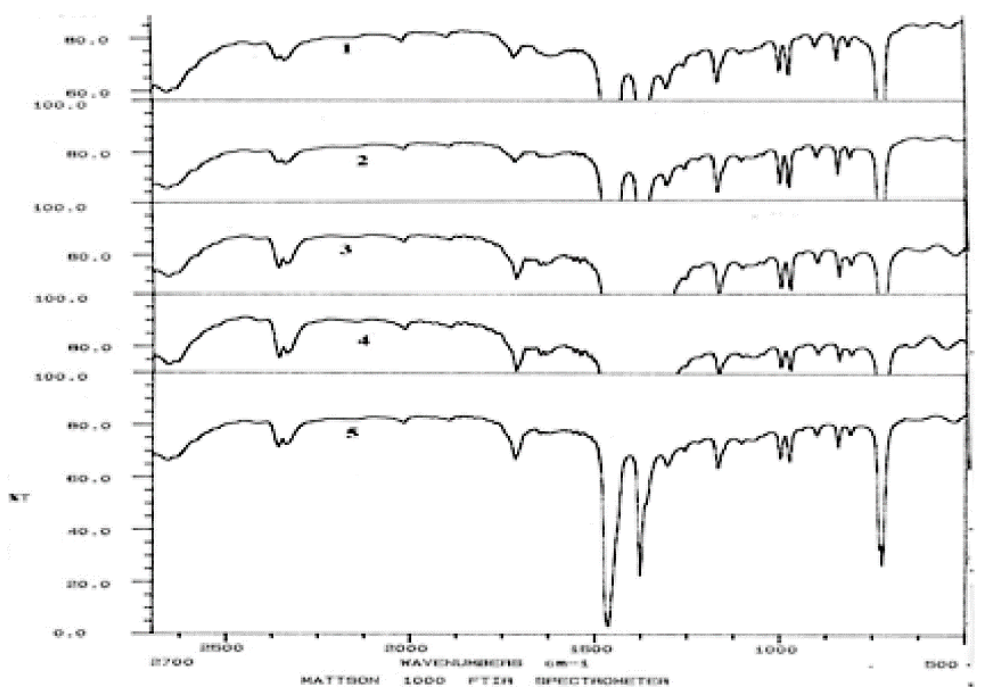

Fig. 5. IR spectra of PE: $1-t=0 ; 2-t=3$ hours; $3-t=5$ hours; $4-t=10$ hours; $5-t=15$ hours $\left(U=9 \cdot 10^{3} \mathrm{~V}\right)$.

dant; for $t=15$ hours, the decrease in $E$ for the nanocomposite and $\mathrm{PE}$ is $35 \%$ and $43 \%$, respectively, and the increase in $D_{1720}$ for both samples is $50 \%$.

It is clear from the Fig. 4 and Table that, after exposure to the stabilizing factor for both samples, an increase in $E$ corresponds to a decrease in $D_{1720}$. The values of $E$ for the nanocomposite and PE before and after orientation are given in Table. It can be seen that, depending on the degree of orientation, the value of $E$ in pure $\mathrm{PE}$ is higher compared to the nanocomposite. The role of the additive in these processes is different (destructive and stabilizing ones). The 


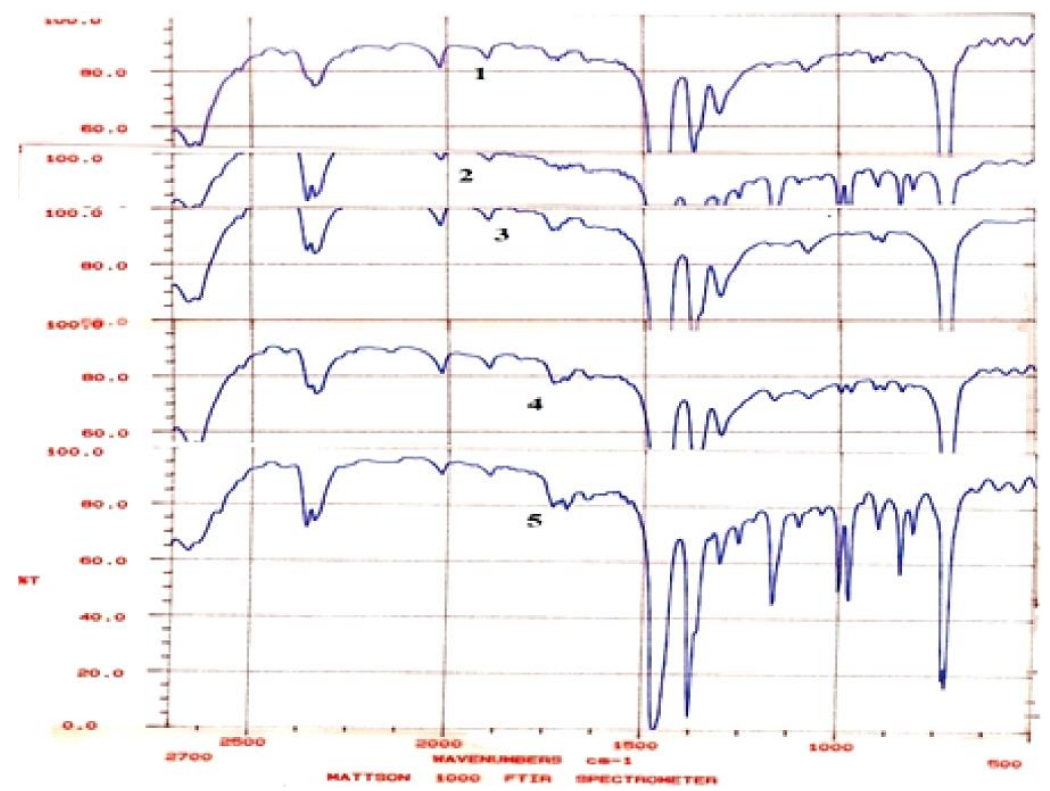

Fig. 6. IR spectra of $\mathrm{PE}+3.0 \% \mathrm{NC}$ nanocomposite: $1-t=0 ; 2-t=3$ hours; $3-t=5$ hours; $4-t=10$ hours; $5-t=15$ hours $\left(U=9 \cdot 10^{3} \mathrm{~V}\right)$.

TABLE.

\begin{tabular}{|c|c|c|c|c|c|c|}
\hline \multirow[b]{2}{*}{ Samples } & \multicolumn{2}{|c|}{$E, \times 10^{6} \mathrm{~V} / \mathrm{m}$} & \multirow[b]{2}{*}{$\begin{array}{c}\Delta E, \% \\
\text { decrease }\end{array}$} & \multicolumn{2}{|c|}{$E, \times 10^{6} \mathrm{~V} / \mathrm{m}$} & \multirow[b]{2}{*}{$\begin{array}{c}\Delta E, \% \\
\text { increase }\end{array}$} \\
\hline & \begin{tabular}{|c|} 
nonaged \\
$U=0$ \\
$t=0$
\end{tabular} & $\begin{array}{c}\text { aged } \\
U=9 \mathrm{kV} \\
t=15 \text { hours }\end{array}$ & & nonoriented & $\begin{array}{c}\text { oriented } \\
\lambda=2.5\end{array}$ & \\
\hline $\mathrm{PE}$ & 70 & 40 & 43 & 70 & 95 & 36 \\
\hline $\mathrm{PE}+3 \% \mathrm{NC}$ & 54 & 35 & 35 & 54 & 67 & 25 \\
\hline
\end{tabular}

influence of $\mathrm{NC}$ on destructive processes is much greater than on stabilizing ones.

A number of studies [11-13] have shown the influence of supramolecular structure on dielectric strength of polymer dielectrics. Orientation drawing is one of the main physical methods for changing the supramolecular structure of polymers and, as a result, the effect on their most important operational properties, including the dielectric strength of polymers.

Thus, despite the fact that the nanoclay introduced into the polymer in some cases affects the supramolecular structure, the orientation process prevails in this case. Based on experimental data, we can conclude that nanoclay plays an active role only in processes where destructive processes prevail. 


\section{CONCLUSIONS}

Summarizing the findings on the effects of electric ageing and the orientation drawing on the dielectric strength of $\mathrm{PE}$ and $\mathrm{PE}+3.0 \%$ $\mathrm{NC}$, it can be concluded that introduction of nanoclay, preventing destructive processes, has a stabilizing (reinforcing structure) effect, thereby making it possible to obtain polyethylene films with more stable electrical and mechanical properties.

\section{REFERENCES}

1. Y. L. Ozcanlı, F. S. Boydag, V. A. Alekperov, I. Hikmet, and M. Canturk, Mod. Phys. Lett. B, 21, No. 21: 1415 (2007); https://doi.org/10.1142/S0217984907013663

2. $\quad$ A. Akinci, J. Reinf. Plast. Compos., 29, No. 7: 957 (2010); https://doi.org/10.1177/0731684408101426

3. M. A. Ramazanov, S. A. Abasov, R. L. Mamedova, and A. A. Resulova, Surf. Engin. Appl. Electrochem., 47, No. 6: 481 (2011); https://doi.org/10.3103/S1068375511060160

4. Y. Ozcanli, M. Beken, F. Kosovali Cavus, A. A. Hadiyeva, A. R. Sadigova, and V. A. Alekperov, J. Nanoelectron. Optoelectron., 12: No. 4: 316 (2017); https://doi.org/10.1166/jno.2017.2017

5. A. R. Sadygova, I. I. Abbasov, E. S. Safiev, P. B. Asilbeyli, and V. A. Alekperov, Nanosistemi, Nanomateriali, Nanotehnologii, 17, No. 1: 155 (2019) (in Russian); https://doi.org/10.15407/nnn.17.01.155, https://www.imp.kiev.ua/nanosys/media/pdf/2019/1/nano_vol17_iss1_p015 5p0165_2019.pdf

6. R. A. Vaia, H. Ishii, and E. P. Giannelis, Adv. Mater., 8: 29 (1996).

7. H. R. Dennis, D. L. Hunter, D. Chang, S. Kim, J. L. White, J. W. Cho, D. R. Paul, Polymer, 42, No. 23: 9513 (2001); https://doi.org/10.1016/S0032-3861(01)00473-6

8. F. Ş. Boydağ, Y. L. Özcanli, V. A. Alekperov, and I. Hikmet, Compos. Part $B$, 37, Nos. 2-3: 249 (2006); https://doi.org/10.1016/j.compositesb.2005.05.014

9. C. Yumusak and V. Alekberov, Fibers Polym., 9, No. 1: 15 (2008); https://doi.org/10.1007/s12221-008-0003-7

10. G. B. Abdullayev, S. A. Abasov, Ya. G. Ragimov, and V. A. Alekperov, Dokl. Akad. Nauk AzSSR, 44, No. 1: 56 (1983) (in Russian).

11. A. R. Sadygova, A. A. Khadiyeva, V. A. Alekperov, and M. A. Ramazanov, Azerb. J. Phys., 24, No. 4: 14 (2018) (in Azerbaijani).

12. Ehlektricheskie Svoistva Polimerov [Electrical Properties of Polymers] (Ed. B. Sazhina) (Leningrad: Khimiya: 1986) (in Russian).

13. A. M. Magerramov, Strukturnoye i Radiatsionnoye Modifitsirovanie Ehlektretnykh, P'iezoehlektricheskikh Svoistv Polimernykh Kompozitov [Structural and Radiation Modification of Electret, Piezoelectric Properties of Polymer Composites] (Baku: Elm: 2001) (in Russian). 